\title{
Science in Sustainability: A Theoretical Framework for Understanding the Science-Policy Interface in Sustainable Water Resource Management
}

\author{
Edward Morgan, Griffith University, Australia
}

\begin{abstract}
Attempts to create sustainable water resource management (WRM) face substantial challenges from population growth, expanding urbanisation, environmental degradation, and anthropogenic climate change. Science can provide vital knowledge and understanding to help create sustainable policy outcomes. However, the interactions between science and policy can be problematic, limiting the ability of science to contribute to sustainability. There needs to be better understanding of how science is used within WRM in order to identify the most effective uses of science. This paper will present an emerging theoretical framework for analysing how and why science is used within policy. This work considers that scientific knowledge and understanding are used widely within the policy networks of WRM, not just where scientists and policymakers meet, and hence that there is not one science-policy interface but many. To help better understand these interfaces, the framework is developed from concepts in the water governance and science-policy interface literature combined with the recognition that science is complex and evolving. The framework presented here will provide a tool to better understand the role of science within sustainable WRM by analysing the factors that might affect the use of science by stakeholders.
\end{abstract}

Keywords: Science-Policy Interface, Governance, Natural Resource Management

\section{Introduction}

$\mathrm{T}$ The importance of science for sustainability has long been recognised (Brundtland and World Commission on Environment Development 1987, ch. 12, p.254, United Nations 2002, point 28, p. 22), and many water resource management (WRM) policies and plans that aim for sustainability call for the use of the 'best-available science' (see for example the Australian National Water Initiative and the European Water Framework Directive). However, significant concerns have been raised about the use of science in WRM. Increasing knowledge does not seem to be leading to more sustainable management (Hart and Calhoun 2010). Although the use of science is unlikely to be the only barrier to sustainable outcomes, limitations to the effective use of science within policy are a significant problem for natural resource management. In WRM, Cullen highlighted problems of knowledge transfer (due to differing expectations and communication), uncertainty and the politicisation of science back in 1990 (Cullen 1990), and little appears to have changed (Hillman and Brierley 2002, Borowski and Hare 2006, Rogers 2006, Lagacé, Holmes, and McDonnell 2008, Macleod, Blackstock, and Haygarth 2008, Eberhard et al. 2009, Ryder et al. 2010, Tomlinson and Davis 2010). While several solutions have been proposed, such as knowledge brokering (Cullen 1990), more policy-relevant science (Hart and Calhoun 2010), adaptive management (Hillman and Brierley 2002, Richter et al. 2006, Eberhard et al. 2009) and integration (Quevauviller et al. 2005, Rogers 2006, Macleod, Blackstock, and Haygarth 2008, Eberhard et al. 2009, Tomlinson and Davis 2010, Gawne, Crase, and Watson 2010, Robinson et al. 2011), there is little agreement on how best to ensure science is used effectively within WRM. Notably, the discussions of these problems and solutions imply very different uses for science in policy and tend to consider science as a single entity. Understanding how and why science is used is essential if successful sustainable management of water resources is to be achieved. As Dovers (2005, p. 29) points out: "Coupled with uncertainty

The International Journal of Sustainability Policy and Practice

Volume 9, 2014, onsustainability.com, ISSN: 2325-1166

(C) Common Ground, Edward Morgan, All Rights Reserved

Permissions: cg-support@commongroundpublishing.com

$\left(\begin{array}{lllllll} & C & 0 & M & M & O & N \\ \hline & G & R & 0 & U & N & D\end{array}\right.$ 
and long-time horizons, the role of information in sustainability policy is important, complex and poorly understood". A variety of different roles for science within a policy setting have been identified, such as knowledge provider, arbiter, broker, participatory knowledge advisors or even advocate (Pielke Jr 2007, Turnhout et al. 2013), but it is not clear which role will provide the most effective use of science in creating sustainable outcomes. Each role is likely to be more appropriate to different situations, and is likely to face different problems. Consequently, the most effective solution is likely to depend upon a number of different factors. To improve the use of science, it is necessary to analyse how and why science is used and what factors affect its use within policy

This paper proposes an emerging theoretical framework to aid in the analysis of how and why science is used within WRM, in order to try and improve the use of science for sustainability. The framework builds upon existing models of the science-policy interface to consider the use of science in policy network interactions. The paper will examine the development of different perspectives of the science-policy interface in the literature and use a governance approach to policy and a weak social constructionist view of science to determine factors that will influence the use of science in WRM.

First, brief definitions and discussions of WRM policy and science will be provided, to provide a background for the framework development. Then, by expanding existing models of the science-policy interface, an emerging theoretical framework will be developed that allows for the analysis of how and why science is used within science-policy interfaces.

\section{Policy and Water Resource Management}

Water resources are under increasing pressure from rising populations, human water usage, environmental degradation and climate change (UNEP 2007). The importance of water resource management (WRM) in sustainable development was highlighted at the Rio, Rio+10 and Rio+20 summit meetings (United Nations Conference on Environment Development 1992, ch. 18, p. 7, United Nations 2002, Part IV, points 25-29, p. 20-22, United Nations Conference on Sustainable 2012) as well as in the international agreement on sustainable development, Agenda 21 (United Nations Department of Economic and Social Affairs 1992, sec. 2, ch. 18). However, it has been suggested that traditional WRM is a barrier to sustainable water use (Millennium Ecosystem Assessment Board 2005, OECD 2011, Tan, Bowmer, and Mackenzie 2012).

Consequently, policy concerning water in developed countries is heavily focused on sustainable management of water resources, and more recently there has been a trend towards 'integrated water resource management' (IWRM) (Jønch-Clausen 2004, Meire et al. 2008). IWRM considers water management more holistically in terms of the biophysical water cycle, acknowledging that land uses, waste- and stormwater and the environment are just as important to water management as rainfall, water purification and supplying consumers (Thomas and Durham 2003, Mitchell 2005, Davis 2007). These developments have led to the decentralisation of decision-making, as well as a broadening of the context within in which WRM takes place. Thus, water resource policy, in its broadest sense, involves a much wider variety of stakeholders, reaching far beyond centralised government control. Recent reforms in Australia, for example, have seen privatisation, the introduction of water markets and a greater role for the Federal government (as opposed to the traditional State and local control), all increasing decentralisation and involving more and more stakeholders (McKay 2005, Hussey and Dovers 2006, Crase and Dollery 2008, Stoeckel and Abrahams 2007).

This has led to a focus on the 'governance' of water resources (see e.g. Rogers and Hall (2003), Doolan (2007), Galaz (2007), Huitema et al. (2009), Tan, Bowmer, and Mackenzie (2012)). A governance approach is based on the idea of policy networks: Rhodes (2007, p. 1246) defined governance as "governing with and through networks". It recognises that decisions are made within complex policy networks involving a wide variety of stakeholders and tries to 
understand how these networks operate and how interactions shape decisions and policy (see e.g. Rhodes (1997), Stoker (1998), Adger et al. (2003), Wallington and Lawrence (2008)). Notably, many of the factors suggested to improve governance such as trust, legitimacy, accountability, adaptive management and co-learning (e.g. Rhodes (2007), Wallington, Lawrence, and Loechel (2008), Lockwood et al. (2010)) are also reflected in discussions on the use of science in policy (e.g. Jasanoff (1996), Pouyat (1999), Cash et al. (2002)). The concept of interactions within a network corresponds to the concept of science-policy interfaces, where science and policy interact (see later). Here, the development of a framework will use a governance approach to policy, with an emphasis on understanding the use of science in network interactions.

\section{Science}

WRM draws upon a wide range of scientific knowledge, and due to the importance of both natural and social processes within WRM this includes both biophysical and social sciences. Furthermore, using the distinctions drawn by Funtowicz and Ravetz (1993), it includes core science, applied science, consultancy and even 'post-normal' science. Any understanding of the use science in WRM needs to account for this variety.

The word science can represent both scientific knowledge and the process that creates it (sometimes referred to as the scientific method). Science is often expected to produce 'truthful' objective knowledge about the real world, and hence a source of facts that can be used to solve problems, answer questions and make predictions. This realist view implies that science can provide knowledge about the real world that should be considered unique, special and truthful, and hence a good basis for evidence-based policy.

However, there is significant debate about the nature of science, with little agreement about what constitutes the 'scientific method' (Chalmers 1999), whether such a method exists (Feyerabend 1993) or if a defined method is needed to render science objective (Bauer 1992). The lack of an identifiable scientific method is used to suggest that scientific knowledge is socially constructed, and thus that scientific knowledge is no different to any form of knowledge and has no claim to providing objective 'truth' so should be considered equally to other knowledge types (Feyerabend 1978).

These realist and social constructionist views represent two ends of a spectrum. In between, weak social constructionism maintains that there is real world that science can describe but that scientific theories are, to some extent, socially constructed. This view, perhaps best represented by the work of Thomas Kuhn (1996), suggests science can create objective knowledge through social processes, but that it may only imperfectly represent reality.

The view of science used here draws on the work of Kuhn and more contemporary pluralistic views of the philosophy of science (Kuhn 1996, Pickett, Kolasa, and Jones 2007). Science is seen as a process that results in an understanding of the world through theories (Hull 1990, Pickett, Kolasa, and Jones 2007). Scientific theories, however, are not a simple statements of fact (as a traditional understanding might suggest), but complex constructions made up of a number of components, such as assumptions, concepts, definitions, facts, generalisations, laws and hypotheses, models and frameworks to link the components together (Pickett, Kolasa, and Jones 2007). As science proceeds, the components of the theory may change and develop, and potentially the theory can be discarded and a new one developed. Theories are tested against the real world and debated within the scientific community. Objectivity arises from the fact that the science process is open to change based on its engagement with the material world, and the openness of the dialogue within a diverse community (Pickett, Kolasa, and Jones 2007). Theories operate within paradigms, which consists of the worldview, beliefs, assumptions and techniques, and problem solutions that are held in common by a scientific community (Kuhn 1996). This is a weak social constructionist perspective that recognises science is socially constructed, but argues that it is able to provide objective, if imperfect, understanding of the real world. 
This pluralistic view of science has consequences for the use of science in policy (Sarewitz 2004). Science can not be considered a simple homogenous block of knowledge, but as a complex process of understanding created within a large number of different paradigms. This implies, however, that it is important to consider the nature of the science that is being used in WRM and not regard it as simply a block of objectively 'true' facts.

\section{The Science-Policy Interface}

A science-policy interface approach is a useful way to conceptualise the interactions between science and WRM. It recognises that science and policy are separate entities, with different methods, institutions and aims, and consequently that where they interact there is an interface (van den Hove 2007).

The interface approach has been used to identify and explain the problems within sciencepolicy interactions in water management (e.g. knowledge transfer, uncertainty, politicisation (Cullen 1990, Galaz 2007)), and methods for overcoming these barriers (e.g. boundary work, adaptive management, integration (Richter et al. 2006, Rogers 2006, Macleod, Blackstock, and Haygarth 2008, Tomlinson and Davis 2010)). What is less clear, however, is which approach to managing the interface is most suitable in any given situation. In order to establish which solution is likely to be effective it is necessary to understand the interface is greater detail. The following discussion will describe the development of a theoretical framework that builds on existing models of the interface, in order to better understand how and why science is used in policy.

\section{Models of the Science-Policy Interface}

There are a number of ways to model the science-policy interface, reflecting different ways of thinking about science and policy. The worlds of both policy and science are complex, nebulous and always changing, and describing the interface requires simplifying them.

The simplest model is the idea of a linear producer-user relationship between science and policy, with science providing knowledge for policy-makers to use (Sarewitz and Pielke Jr 2007). This is often seen as too simple (Landry, Amara, and Lamari 2001, Slob et al. 2007), and suggests that the only role of science is to act as a knowledge provider. More common is the idea that science and policy are two separate communities that can overlap (Albaek 1995, Slob et al. 2007, Landry, Amara, and Lamari 2001). This view is often depicted as a simple Venn diagram (Figure 1).

Figure 1: A simple model of the science-policy interface, based on the 'two-communities' view of science and policy.

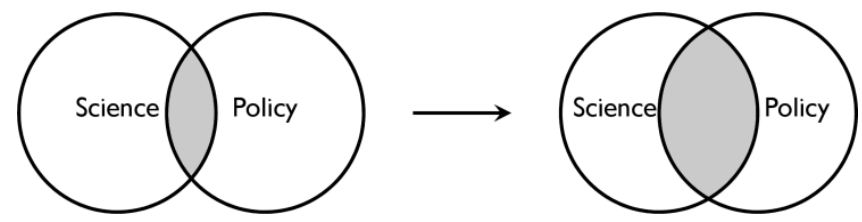

This conceptualisation hihglights that science and policy encompass different ideas, frames of reference, spaces and communities, and where they meet they have to overlap and interact. It emphasises that the differences between the communities will give rise to communication problems and differing (and conflicting) expectations. Improving the interface is done by increasing the overlap between science and policy so that the activities share more ideas and understanding. Simplistically, integration can be seen as making science more suitable for policy needs (Pouyat 1999, Hart and Calhoun 2010, Tomlinson and Davis 2010), while adaptive 
management can be seen as taking a more 'scientific' approach to policy (using experiment and feedback) (Eberhard et al. 2009, Pagan 2008, Holling 1978). People or organisations working at the overlap, aiding the understanding between the separate communities or activities, can be described as knowledge brokers (Cullen 1990) or boundary organisations (Guston 2001). This picture does provide a starting point for understanding science-policy interactions; however it fails to reflect the complexity of policy or science. While providing a very broad overview, it does not allow for more detailed analysis or understanding. Policy can rarely be represented by a single community or activity; and while science can be seen as a single community driven by a common aim of increasing understanding, as previously discussed this is also too simplistic. Furthermore, there is no place for other communities. Moves towards IWRM recognise the importance of the community, industry and other stakeholders.

An alternative model for understanding the use of science expands this simple picture by suggesting that there is a 'trialogue' or 'triple interface' (Figure 2) (Godfrey 2007, Gooch and Stålnacke 2010). Developed in order to try and understand and assess governance in IWRM, this model proposes that there are interfaces between science, society and government (Turton et al. 2007). It suggests that drivers to good (environmental) governance come from government, society and science and the interactions between them.

Figure 2: The trialogue model of the science-policy interface. Adapted from (Godfrey 2007).

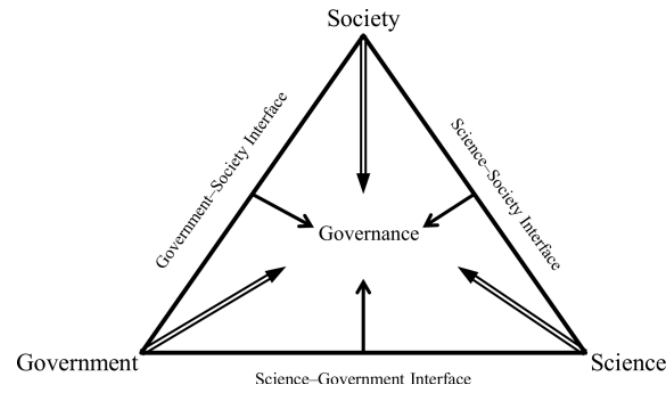

This idea has been used by several authors to look at aspects of the interactions between science and policy in water management, including explaining the problems faced by water managers (see Gooch and Stalnåcke 2010). Not only does this approach allows for greater complexity in thinking about how science might influence policy by incorporating societal interactions, it emphasises the link between governance and the science-policy interface that has been noted elsewhere (Miller 2001, Bäckstrand 2003). This suggests that improving governance and improving the interface amount to much the same thing. Trust, legitimacy, adaptive management, collaboration/integration and co-learning are common features of both the governance (e.g. Rhodes (2007), Wallington, Lawrence, and Loechel (2008), Lockwood et al. (2010)) and science-policy literature (e.g. Jasanoff (1996), Pouyat (1999), Cash et al. (2002), (Grizzetti et al. 2010)).

The model provides a link between IWRM, governance and science. It shows how science has a more complex role than simply providing knowledge or understanding, but is an integral part of establishing good governance. However, the trialogue model, like the two-communities model, sees science as a homogeneous community. Also, it sees the interactions between science and policy as existing only where the science community comes into contact with the policy process; science as an external driver to governance. In WRM, however, all stakeholders can have access to, and will use science differently to influence the process.

Interestingly, Kasperson addressed some of these issues by discussing the science-policy interface in terms of a mediating network, or 'spider's web' (Kasperson 2011). This model 
replaces a simple interface between science and policy with a web of interactions (Figure 3). Kasperson suggested characterising these webs as simple, complex but stable or complex and unstable, dependent upon the stability and complexity of the institutions involved.

Figure 3: Kasperson’s spider's web model of the science-policy interface. Reproduced with permission from Kasperson (2011).

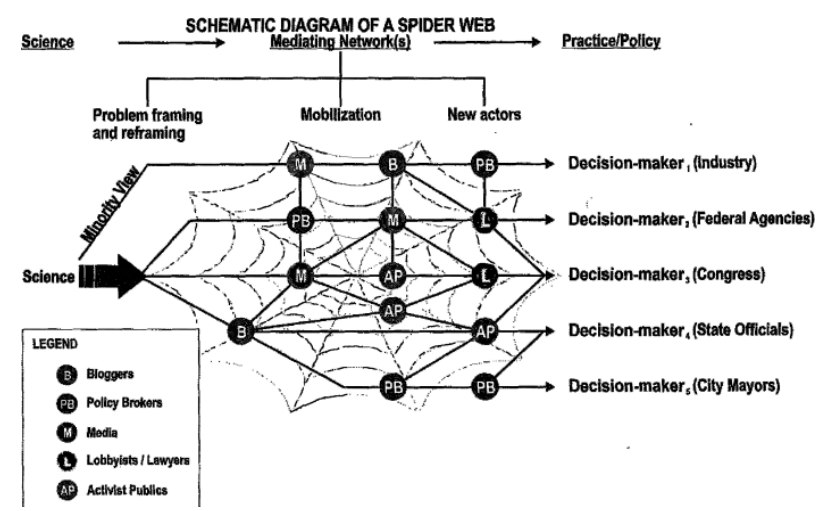

Clearly, parallels can be drawn between the idea of a web, and the ideas of policy networks that underpin governance. The link to governance is retained, but now instead of science as an external driver of the governance process it becomes something used within the governance network. Kasperson's characterisation of networks helps understand how these networks might be set up and why they might succeed or fail, but it doesn't directly address the question of how or why science might be used within these networks. It does, however, suggest that the interactions within the network, which will ultimately determine the complexity and stability, are key to understanding the network and the use of science within it.

\section{An Emerging Theoretical Framework for Understanding the Science-Policy Interface in WRM}

The spider's web model of the interface implies that in fact there is not one interface but many, potentially involving a large number of different stakeholders. The importance of involving stakeholders in IWRM suggests that this model might be appropriate for understanding the use of science in WRM. The science-policy interface now becomes a number of individual interfaces occurring wherever science is used within interactions between stakeholders. In this case, it is necessary to understand the factors that influence the interactions in the policy network, and what impact this will have on the use of science.

\section{Interactions in Policy Networks}

The governance literature provides several concepts that are important to understanding policy network interactions and that will impact the use of science.

Firstly, and most simply, is the purpose of the interaction. The interaction will have an ultimate purpose in mind, which will influence how the science is used. The range of purposes will be context dependent, but potentially the stages of the policy cycle (e.g. issue identification, policy analysis, policy instruments, consultation, coordination, decision, implementation, evaluation) (Bridgman, Althaus, and Davis 2007) may provide a useful guide to understanding the purpose of any particular interaction. Identifying an issue, for example, may use science to 
raise awareness or educate stakeholders, while policy analysis may use science to prioritise actions based in their predicted impacts. Science can play a role in coordinating stakeholders by providing a shared understanding, or provide the means to communicate the policy in consultation. Each purpose may imply a very different use of science. Other typologies of collaboration efforts in environmental management or policy advice also exist (e.g. Margerum (2008), Hamburger and Weller (2012)) which may better fit in other contexts, but the policy cycle provides a well-established way of analysing the aims of policy for sustainability (Dovers (2005))

Additionally, it is important to consider any specific agendas of stakeholders-aims that might range from explicitly stated to not even consciously known, but nonetheless will affect the use of science in the interaction. If the science supports the agenda, then it is likely to be emphasised, promoted and shared, alternatively if it contradicts agendas it may be used more selectively and is unlikely to be successful in a brokering role. Individual agendas are more difficult to generalise as they are dependent on the individuals and the context. However, Wanna combines the purpose of the collaboration and individual motivations into a table of context, purpose, choices and motivations, which provides some insight into the choices stakeholders might face (Wanna 2008).

The nature and intensity of the interactions are also likely to influence the use of science. Whether the interaction within in the network is a formal and long-term arrangement or simply informal and transient will influence the use of science, as highlighted by Kasperson (2011). Here, discussions of participation and collaboration provide ways of analysing the interaction. Participation and collaboration have been identified as key concepts in water management and governance (Huitema et al. 2009, Gawne, Crase, and Watson 2010, Tan, Bowmer, and Mackenzie 2012), as well as in governance more generally (Newman et al. 2004, Wanna 2008), and for science in governance (Bäckstrand 2003, Hagendijk and Irwin 2006). Analysis of participation could use the 'ladder of participation' proposed by Arnstein (1969). Greater participation suggests that science must be shared. Simple informing will likely involve one participant using science to provide knowledge; participatory decision-making suggests that the science is more likely to be used to develop understanding, in a co-learning process. Additionally, collaborative governance literature suggests different levels of collaboration. Wanna suggests five levels of collaboration (low, medium-low, medium, medium-high and high) and discusses the activities that characterise each level (Wanna 2008). The lowest level is characterised by consultation and discussion, while the highest involves "transformative interactions". Again, consultation is likely to use science as facts to inform others, while transformative interactions might use science as a collaborative exercise, with scientific understanding changing as part of the process.

Other factors are also likely to affect the interaction, but these four provide a substantial level of complexity, and have analytical grounding within the literature. It is important to note that they are all linked and influence one another, potentially in quite complex ways. The level of participation may limit what agendas the actor may be able to bring to the table, for example, or the purpose of the interaction may very well define the level of participation of an actor. 
Table 1: Summary of key influences on the interactions between stakeholders that might affect the use of science in policy.

\begin{tabular}{|c|c|c|}
\hline Concept & Influence on interaction & Example from literature \\
\hline Purpose & $\begin{array}{c}\text { The reason the interaction has formed (whether } \\
\text { formally or informally) }\end{array}$ & $\begin{array}{c}\text { Policy cycle (Bridgman, } \\
\text { Althaus, and Davis 2007) }\end{array}$ \\
\hline Agenda(s) & $\begin{array}{c}\text { Personal values and priorities that may influence } \\
\text { stakeholders' view or approach to the interaction }\end{array}$ & $\begin{array}{c}\text { Motivations (Wanna } \\
\text { 2008) }\end{array}$ \\
\hline Nature & $\begin{array}{c}\text { An indication of the influence stakeholders will } \\
\text { have on the interaction }\end{array}$ & $\begin{array}{c}\text { Ladder of Participation } \\
\text { (Arnstein 1969) }\end{array}$ \\
\hline Intensity & $\begin{array}{c}\text { An indication of how closely the stakeholders are } \\
\text { interacting, from consultation/discussion through } \\
\text { to co-learning and co-developing }\end{array}$ & $\begin{array}{c}\text { Levels of collaboration } \\
\text { (Wanna 2008) }\end{array}$ \\
\hline
\end{tabular}

\section{Science Within Interactions}

It is also necessary to consider the science within the interaction, as this will affect how and why it is used. Most fundamentally, perhaps, is the question of a need for science. Does the actor in fact require any level of scientific information, knowledge or understanding to carry out their role? The answer to this will be defined by the issue-here in considering sustainable WRM it is assumed that there is a need for science. The popularity of evidence-based policy and regular calls for the use of the 'best available science' in policy documents suggest that science will always have a role to play.

Assuming that science is to be used, it is important to consider the nature of the science being used. The previous discussion noted that science is not a body of factual statements, but a process of creating paradigms and theories, with the understanding that is created evolving and changing over time. Thus, it is necessary to consider the characteristics of the science that may affect its use within a policy interaction. Selecting characteristics that describe the science is not straightforward, and is made more complex when the use of science in policy is considered. In choosing relevant characteristics it is important to consider factors that describe properties of the science itself, as well as characteristics that are relevant to its use in policy.

Turning first to the characteristics of science as it proceeds within the scientific community, Kuhn identifies 'normal' science as problem solving within a paradigm (Kuhn 1996) based upon the gathering of evidence for theories, by testing them against real world observations, and the development of consensus around those theories. Ultimately, a scientific theory moves towards becoming part of the accepted paradigm by gathering evidence to support it and through a consensus forming around it.

The amount of evidence and the scientific consensus determine how 'sound' the science is. Science that is well-tested and widely-accepted is scientifically sound, and is likely to be wellestablished and developed or 'textbook' science. Science that is less well-developed may be 'frontier science', and will be more speculative and more contentious (Pickett, Kolasa, and Jones 2007). Stakeholders are more likely to have confidence in well-established and widely supported science.

At the same time, because theories are only ever imperfect descriptions of the world based on incomplete data sets, and because nature is complex and variable, there is always uncertainty in science (Pickett, Kolasa, and Jones 2007). The level of uncertainty, however, is different for different types of science. Physics may deal with very controlled conditions where ideas can be 
tested repeatedly, whereas ecology deals with the complexity of the natural world. Thus, evidence, consensus and uncertainty are 'internal' characteristics of science important to the use of science in WRM.

However, it is important to recognise that when science is used within a policy (or more generally a social) sphere there are other characteristics that will become important. Firstly, the availability of the science will be important—both whether the scientific data, knowledge or understanding exists and whether it is accessible or understandable to those outside the scientific community that produced it. If science has limited availability, stakeholders are likely to demand more research or rely on other knowledge. Science designed for use in policy, or conducted with a particular aim in mind (policy relevant) may be more accessible and understandable, and hence used more effectively (Norse and Tschirley 2000, Watson 2005).

Finally, it is important to consider the issue of values in the use of science. Values are an important part of policy, and expecting science to replace them, or solve value-conflicts is unrealistic and damaging to the policy process (Weingart 1999). Although science is often considered 'value free', it is important to note that science is performed by scientists who hold values. The open and non-authoritarian process of science tries to create objectivity and reduce bias through participation of a diverse range of people, and consensus forming through peerreview (Pickett, Kolasa, and Jones 2007). Nonetheless, values will be a part of science, especially in areas such as sustainability, which is inherently a value-based concept (Lélé and Norgaard 1996). For example, environmental scientists will talk of degradation, implying a negative value, when discussing changes to the environment reflecting their valuing of nature (Lackey 2007). Furthermore, the policy process is always value-based and so scientific knowledge and understanding will become value-laden when used in policy. For example, the science of the how long bacteria survive in water becomes significantly value-laden in the context of public health and water supply safety; 'short' or 'long' survival times translate into 'good' and 'bad'-values defined by the issue of public health. Any value character that the science takes on will impact upon its use. In the ideal situation where science is 'value-free', it can be used to guide policy options and act as the 'honest broker' (Pielke Jr 2007), providing knowledge and guidance into a policy process, e.g. establishing the quantity of water available to guide the need for policy changes. However, if the science takes on some level of value character, the value overlap with the values of the stakeholders will influence its use. If the values in the science support the values of an actor, the actor is likely to use science to advocate their position. The science may become part of a political conflict and highly politicised (Pielke Jr 2002). In WRM, attempts to combat opposition to recycled water can rely on using science and expert advice to overcome community opposition, often with limited success (Hurlimann and Dolnicar 2010). Thus, availability, value character and value overlap will influence how science is used in policy.

These 'characteristics' of science (Table 2) will strongly influence how and why it is used within WRM. Note that these characteristics will not be entirely independent, but will influence each other. In particular, evidence consensus and uncertainty are closely linked, and the value overlap will clearly be affected by value the value character. Availability is less tied to the others, although well-established science is more likely to be available and easier to communicate than frontier science. 
Table 2: Characteristics of science that will influence its use in policy.

Evidence

Consensus

Uncertainty

Availability

Value character

Value overlap
The amount of empirical evidence in support of the science. This reflects the importance of observation and experimentation in science.

The level of consensus within the scientific community reflects how well-established the science is.

Natural variability and lack of empirical evidence combine to make all science uncertain. Different levels of uncertainty are more acceptable in different areas of science.

Covering issues of both access and communication, it is important to consider whether the science is available and accessible.

Scientific can reflect the values of scientists or stakeholders using it.

Any value character may conflict or overlap with other social or individual values within the policy network.

\section{The Science-Policy Interface Within Policy Network Interactions}

A new conceptualisation of the factors that will influence science-policy interface in WRM is presented here, which focuses on the interactions of stakeholders in a policy network (Figure 4). The framework takes a governance approach to understanding these interactions and considers the characteristics of the science used within the interactions. 
Figure 4: An emerging theoretical framework for the science-policy interface.

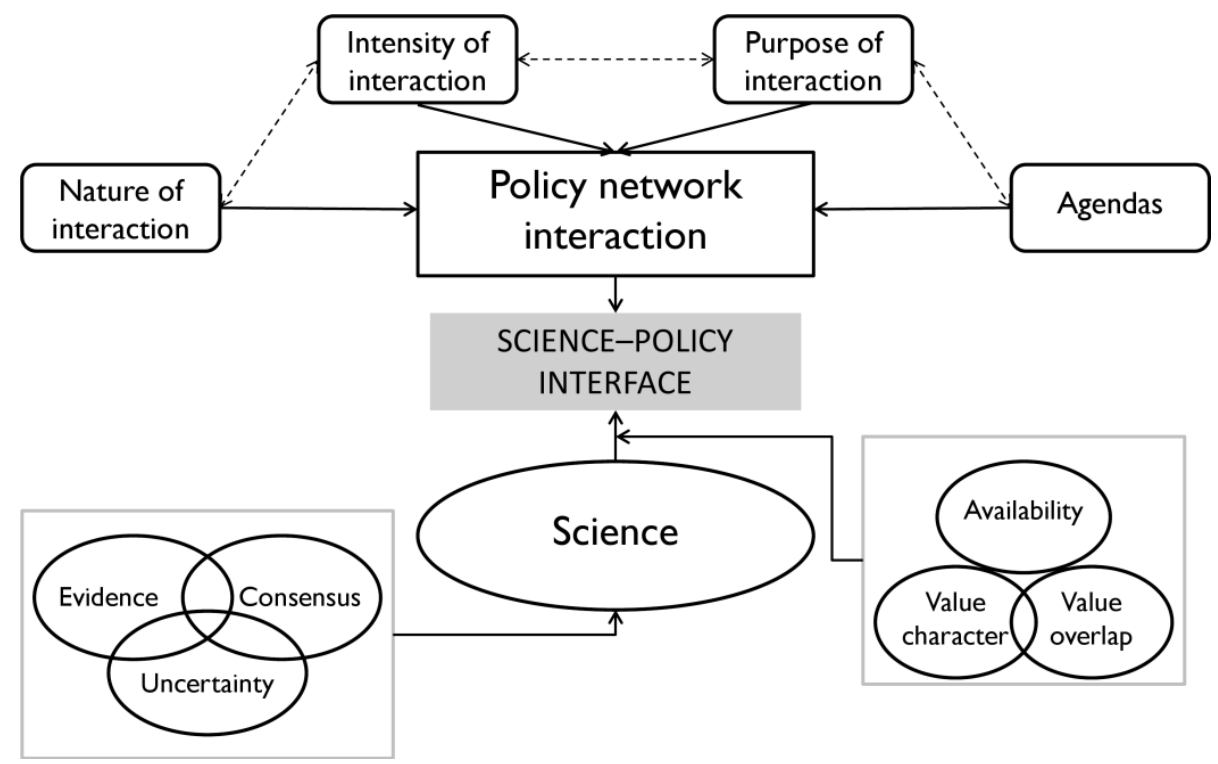

This framework suggests a variety of factors, based on concepts grounded in the literature, that might affect how and why science is used within policy network interactions:

- $\quad$ Purpose of interaction, nature of interaction, intensity of interaction, specific agendas

- $\quad$ Evidence, consensus, uncertainty; availability, value character, value overlap

Investigating and analysing these factors should provide an understanding of how and why science is used. Note that the framework allows for analysis of the interface in any policy interaction where science is being used, not just where 'scientists' communicate science to 'policy-makers'. In other words, there are many science-policy interfaces within a policy network, all of which may potentially be using science differently for different reasons, and so will face different problems and will need different solutions if science is to be used effectively. This framework allows for analysis of science within WRM where modern approaches demand the use of multiple stakeholders, through collaboration and participation, and the use of a diversity of scientific knowledge.

The framework allows different roles of science to be linked to the science and the governance arrangements that exist in a particular context. This understanding can then help to establish which problems are likely to be encountered (e.g. communication, uncertainty and politicisation), and which method(s) to improve the interface (e.g. policy-relevant science, integration or boundary work) are likely to be effective. This will help practitioners better manage the science-policy interface, and thus ensure more effective use of science. A case study of WRM in South east Queensland, Australia will provide data for the validation, testing and refinement of the framework, in order to show how it can be used to link the role of science to managing the science-policy interface.

The difficulty in analysing the use of science in WRM is the complexity of both. This framework tries to acknowledge the 'messiness' of policy and the pluralistic nature of science. Inevitably, however, it involves a simplification. It only ever takes a snapshot in time, for example. Policy interactions can involve many changing stakeholders, and the levels of collaboration and participation are likely to change over time. The framework attempts to represent some of the complexity of the process while still acting as an effective analytical tool, but it will not be comprehensive-other factors may be more important in different contexts. There will be policy contexts in which interactions are limited, as in traditional command and 
control top-down approaches. Finally, it is important to stress that more effective use of science does not guarantee a sustainable outcome; there are many other issues and factors that contribute to outcomes. However, better governance of science and better science-policy interfaces will ensure that science is not limiting outcomes.

\section{Conclusion}

The theoretical framework brings together understanding of governance, science and the sciencepolicy interface in order to link the role of science to the problems and solutions faced by those using science in WRM. It expands on existing models of science-policy interfaces to consider factors that will influence how and why science is used within a policy network. Focusing on policy interactions, through a governance approach, and considering science to be open process and not a simple homogeneous block of knowledge, suggests that any policy interaction that involves science will be a different science-policy interface. The framework then provides a way of analysing these many science-policy interfaces. The framework will help identify why some interfaces seem to be more or less problematic than others, and provide a way of understanding what methods might be useful in overcoming problems, thus allowing for good governance of science-policy interfaces. 


\section{REFERENCES}

Adger, W. Neil, Katrina Brown, Jenny Fairbrass, Andrew Jordan, Jouni Paavola, Sergio Rosendo, and Gill Seyfang. 2003. "Governance for sustainability: towards a 'thick' analysis of environmental decisionmaking." Environment and Planning A no. 35 (6):1095-1110. doi: 10.1068/a35289.

Albaek, Erik. 1995. "Between knowledge and power: Utilization of social science in public policy making." Policy Sciences no. 28 (1):79-100. doi: 10.1007/BF01000821.

Arnstein, Sherry. 1969. "A Ladder Of Citizen Participation." Journal of the American Planning Association no. 35 (4):216-224. doi: 10.1080/01944366908977225.

Bäckstrand, Karin. 2003. "Civic Science for Sustainability: Reframing the Role of Experts, Policy-Makers and Citizens in Environmental Governance." Global Environmental Politics no. 3 (4):24-41. doi: 10.1162/152638003322757916.

Bauer, Henry H. 1992. Scientific Literacy and the Myth of the Scientific Method. Chicago, IL: University of Illinois Press.

Borowski, Ilke, and Matt Hare. 2006. "Exploring the Gap Between Water Managers and Researchers: Difficulties of Model-Based Tools to Support Practical Water Management." Water Resources Management no. 21 (7):1049-1074. doi: 10.1007/s11269-006-9098-z.

Bridgman, Peter, Catherine Eileen Althaus, and Glyn Davis. 2007. The Australian Policy Handbook. Crows Nest, N.S.W: Allen \& Unwin.

Brundtland, Gro Harlem, and World Commission on Environment Development. 1987. Our common future. Oxford: Oxford University Press.

Cash, David W., William C. Clark, Frank Alcock, Nancy M. Dickson, Noelle Eckley, and Jill Jager. 2002. "Salience, credibility, legitimacy and boundaries: Linking research, assessment and decision making." SSRN Electronic Journal. doi: 10.2139/ssrn.372280

Chalmers, A. F. 1999. What is this thing called science? 3rd ed. Indianapolis, Ind: University of Queensland Press.

Crase, Lin, and Brian Dollery. 2008. "The Institutional Setting." In Water policy in Australia: the impact of change and uncertainty, edited by Lin Crase, 74-89. Washington, D.C.: Resources for the Future.

Cullen, Peter W. 1990. "The turbulent boundary between water science and water management." Freshwater Biology no. 24 (1):201-209. doi: 10.1111/j.1365-2427.1990.tb00319.x.

Davis, Matthew D. 2007. "Integrated Water Resource Management and Water Sharing." Journal of Water Resources Planning and Management no. 133 (5):427-445. doi: 10.1061/(ASCE)0733-9496(2007)133:5(427).

Doolan, Jane. 2007. "An Institutional Perspective on Governance - The Evolution of Integrated River Management in Victoria, Australia." In Governance as a Trialogue: GovernmentSociety-Science in Transition, edited by Anthony R. Turton, Hanlie J. Hattingh, Gillian A. Maree, Dirk J. Roux, Marius Claassen, Wilma F. Strydom, Asit K. Biswas and Cecilia Tortajada, 305-317. Berlin, Heidelberg: Springer.

Dovers, Stephen R. 2005. Environment and sustainability policy: creation, implementation, evaluation. Annandale, N.S.W: Federation Press.

Eberhard, Rachel, Catherine J. Robinson, Jane Waterhouse, John Parslow, Barry Hart, Rodger Grayson, and Bruce Taylor. 2009. "Adaptive management for water quality planning from theory to practice." Marine and Freshwater Research no. 60 (11):1189-1195. doi: 10.1071/MF08347.

Feyerabend, Paul K. 1978. Science in a free society. London: NLB.

Feyerabend, Paul K. 1993. Against Method. 3rd ed. London: Verso.

Funtowicz, Silvio O., and Jerome R. Ravetz. 1993. "Science for the post-normal age." Futures no. 25 (7):739-755. doi: 10.1016/0016-3287(93)90022-L. 
Galaz, Victor. 2007. "Water governance, resilience and global environmental change - a reassessment of integrated water resources management (IWRM)." Water science and technology : a journal of the International Association on Water Pollution Research no. 56 (4):1-9. doi: 10.2166/wst.2007.530.

Gawne, Ben, Lin Crase, and Alistair S. Watson. 2010. "Can a collaborative focus on solutions improve our capacity to achieve sustainable water management?" Marine and Freshwater Research no. 61 (7):814-820.

Godfrey, Linda. 2007. "Ecosystem Governance and the Trialogue Debate: An Overview of the Trialogue Relationship and the Engagement along Interfaces." In Governance as a Trialogue: Government-Society-Science in Transition, edited by Anthony R. Turton, Hanlie J. Hattingh, Gillian A. Maree, Dirk J. Roux, Marius Claassen, Wilma F. Strydom, Asit K. Biswas and Cecilia Tortajada, 319-336. Berlin, Heidelberg: Springer.

Gooch, Geoffrey, and Per Stålnacke, eds. 2010. Science, Policy and Stakeholders in Water Management: An Integrated Approach to River Basin Management. London: Earthscan.

Gooch, Geoffrey, and Per Stålnacke. 2010. "Introduction: The Science-Policy-Stakeholder Interface (SPSI)." In Science, Policy and Stakeholders in Water Management: An Integrated Approach to River Basin Management, edited by Geoffrey Gooch and Per Stålnacke, 1-15. London: Earthscan.

Grizzetti, Bruno, Faycal Bouraoui, Geoffrey Gooch, and Per Stålnacke. 2010. "Putting the 'Integration' in the Science-Policy-Stakeholder Interface." In Science, Policy and Stakeholders in Water Management: An Integrated Approach to River Basin Management, edited by Geoffrey Gooch and Per Stålnacke, 17-28. London: Earthscan.

Guston, David H. 2001. "Boundary Organizations in Environmental Policy and Science: An Introduction." Science, Technology \& Human Values no. 26 (4):399-408. doi: 10.1177/016224390102600401.

Hagendijk, Rob, and Alan Irwin. 2006. "Public Deliberation and Governance: Engaging with Science and Technology in Contemporary Europe." Minerva no. 44 (2):167-184. doi: 10.1007/s11024-006-0012-x.

Hamburger, Peter, and Patrick Weller. 2012. "Policy Advice and a Central Agency: The Department of the Prime Minister and Cabinet Policy Advice and a Central Agency." Australian Journal of Political Science no. 47 (3):363-373. doi: 10.1080/10361146.2012.704005.

Hart, David D., and Aram J. K. Calhoun. 2010. "Rethinking the role of ecological research in the sustainable management of freshwater ecosystems." Freshwater Biology no. 55:258269. doi: 10.1111/j.1365-2427.2009.02370.x.

Hillman, Mick, and Gary Brierley. 2002. "Information Needs for Environmental-Flow Allocation: A Case Study from the Lachlan River, New South Wales, Australia." Annals of the Association of American Geographers no. 92 (4):617-630. doi: 10.1111/14678306.00307.

Holling, C. S. 1978. Adaptive Environmental Assessment and Management. London: John Wiley and Sons.

Huitema, Dave, Erik Mostert, Wouter Egas, Sabine Moellenkamp, Claudia Pahl-Wostl, and Resul Yalcin. 2009. "Adaptive water governance: assessing the institutional prescriptions of adaptive (co-)management from a governance perspective and defining a research agenda." Ecology and Society no. 14 (1):26-44.

Hull, David L. 1990. Science as a Process. Chicago, IL: University of Chicago Press.

Hurlimann, Anna, and Sara Dolnicar. 2010. "When public opposition defeats alternative water projects - the case of Toowoomba Australia." Water research no. 44 (1):287-297. doi: 10.1016/j.watres.2009.09.020.

Hussey, Karen, and Steve Dovers. 2006. "Trajectories in Australian water policy." Journal of Contemporary Water Research \& Education no. 135 (1):36-50. 
Jasanoff, Sheila. 1996. "The Dilemma of Environmental Democracy." Issues in Science and Technology no. 31 (1):63-70.

Jønch-Clausen, Torkil. 2004. "“... Integrated Water Resources Management ( IWRM ) and Water Efficiency Plans by 2005” Why, What and How?" Stockholm: Global Water Partnership.

Kasperson, Roger. 2011. "Characterizing the Science/Practice Gap." In Integrating Science and Policy, edited by Roger Kasperson and Mimi Berberian, 3-22. London: Earthscan.

Kuhn, Thomas S. 1996. The structure of scientific revolutions. 3rd ed. Chicago, IL: University of Chicago Press.

Lackey, Robert T. 2007. "Science, scientists, and policy advocacy." Conservation Biology: The Journal of the Society for Conservation Biology no. 21 (1):12-17. doi: 10.1111/j.15231739.2006.00639.x.

Lagacé, Emilie, John Holmes, and Rachael McDonnell. 2008. "Science-policy guidelines as a benchmark: making the European Water Framework Directive." Area no. 40 (4):421434. doi: 10.1111/j.1475-4762.2008.00836.x.

Landry, R., N. Amara, and M. Lamari. 2001. "Utilization of social science research knowledge in Canada." Research Policy no. 30 (2):333-349. doi: 10.1016/S0048-7333(00)00081-0.

Lélé, Sharachchandra, and Richard B. Norgaard. 1996. "Sustainability and the scientist's burden." Conservation Biology no. 10 (2):354-365.

Lockwood, Michael, Julie Davidson, Allan Curtis, Elaine Stratford, and Rod Griffith. 2010. "Governance Principles for Natural Resource Management." Society \& Natural Resources no. 23 (10):986-1001. doi: 10.1080/08941920802178214.

Macleod, Christopher J. A., Kirsty L. Blackstock, and Phil M. Haygarth. 2008. "Mechanisms to Improve Integrative Research at the Science-Policy Interface for Sustainable Catchment Management." Ecology And Society no. 13 (2):48-48.

Margerum, Richard D. 2008. "A typology of collaboration efforts in environmental management." Environmental management no. 41 (4):487-500. doi: 10.1007/s00267008-9067-9.

McKay, Jennifer M. 2005. "Water institutional reforms in Australia." Water Policy no. 7 (1):3552.

Meire, Patrick, Marleen Coenen, Claudio Lombardo, Michaela Robba, and Roberto Sacile. 2008. "Towards integrated water management." In Integrated Water Management: Practical Experiences and Case Studies, edited by Patrick Meire, Marleen Coenen, Claudio Lombardo, Michaela Robba and Roberto Sacile, 1-8. Heidleberg: Springer.

Millennium Ecosystem Assessment Board. 2005. Millenium Ecosystem Assessment. Ecosystems and Human Well-being: Wetlands and Water. Synthesis. Washington, D.C.: United Nations.

Miller, Clark. 2001. "Hybrid Management: Boundary Organizations, Science Policy, and Environmental Governance in the Climate Regime." Science, Technology \& Human Values no. 26 (4):478-500. doi: 10.1177/016224390102600405.

Mitchell, Bruce. 2005. "Integrated water resource management, institutional arrangements, and land-use planning." Environment and Planning A no. 37 (8):1335-1352. doi: 10.1068/a37224.

Newman, Janet, Marian Barnes, Helen Sullivan, and Andrew Knops. 2004. "Public Participation and Collaborative Governance." Journal of Social Policy no. 33 (02):203-223. doi: 10.1017/S0047279403007499.

Norse, D., and J. B. Tschirley. 2000. "Links between science and policy making." Agriculture, Ecosystems \& Environment no. 82 (1-3):15-26.

OECD. 2011. Water Governance in OECD Countries: A Multi-level Approach: OECD Publishing. doi: 10.1787/9789264119284-en. 
Pagan, Phil. 2008. "Adaptive Management." In Water policy in Australia: the impact of change and uncertainty, edited by Lin Crase, 216-229. Washington, D.C.: Resources for the Future.

Pickett, Steward T. A., Jurek Kolasa, and Clive G. Jones. 2007. Ecological Understanding. 2nd ed. Burlington, MA: Academic Press.

Pielke Jr, Roger A. 2002. "Policy, politics and perspective." Nature no. 416:2001-2002.

Pielke Jr, Roger A. 2007. The Honest Broker: Making Sense of Science in Policy and Politics. Cambridge: Cambridge University Press.

Pouyat, R. V. 1999. "Science and environmental policy: making them compatible." BioScience no. 49:281-286.

Quevauviller, Philippe, P. Balabanis, C. Fragakis, M. Weydert, M. Oliver, A. Kaschl, G. Arnold, A. Kroll, L. Galbiati, J. Zaldivar, and G. Bidoglio. 2005. "Science-policy integration needs in support of the implementation of the EU Water Framework Directive." Environmental Science \& Policy no. 8 (3):203-211. doi: 10.1016/j.envsci.2005.02.003.

Rhodes, Rod A. W. 1997. Understanding governance: policy networks, governance, reflexivity and accountability. Bristol, Pa: Open University Press.

Rhodes, Rod A. W. 2007. "Understanding Governance: Ten Years On." Organization Studies no. 28 (8):1243-1264. doi: 10.1177/0170840607076586.

Richter, Brian D., Andrew T. Warner, Judy L. Meyer, and Kim Lutz. 2006. "A collaborative and adaptive process for developing environmental flow recommendations." River Research and Applications no. 22 (3):297-318. doi: 10.1002/rra.892.

Robinson, Catherine J., Richard D. Margerum, Tomas Koontz, Cassandra Moseley, and Sue Lurie. 2011. "Policy-Level Collaboratives for Environmental Management at the Regional Scale: Lessons and Challenges From Australia and the United States." Society \& Natural Resources no. 24 (8):1-11. doi: 10.1080/08941920.2010.487848.

Rogers, Kevin H. 2006. "The real river management challenge: integrating scientists, stakeholders and service agencies." River Research and Applications no. 22 (2):269280. doi: 10.1002/rra.910.

Rogers, Peter, and Alan W. Hall. 2003. Effective Water Governance. Stockholm: Global Water Partnership.

Ryder, Darren S., Moya Tomlinson, Ben Gawne, and Gene E. Likens. 2010. "Defining and using 'best available science': a policy conundrum for the management of aquatic ecosystems." Marine and Freshwater no. 61:821-828. doi: 10.1071/mf10113.

Sarewitz, Daniel R. 2004. "How science makes environmental controversies worse." Environmental Science \& Policy no. 7 (5):385-403. doi: 10.1016/j.envsci.2004.06.001.

Sarewitz, Daniel R., and Roger A. Pielke Jr. 2007. "The neglected heart of science policy: reconciling supply of and demand for science." Environmental Science \& Policy no. 10 (1):5-16. doi: 10.1016/j.envsci.2006.10.001.

Slob, Adrian F. L., Marc Rijnveld, Antony S. Chapman, and Pierre Strosser. 2007. "Challenges of linking scientific knowledge to river basin management policy: AquaTerra as a case study." Environmental Pollution no. 148 (3):867-74. doi: 10.1016/j.envpol.2007.01.048.

Stoeckel, Kate, and Harry Abrahams. 2007. "Water Reform in Australia." In Managing water for Australia: the social and institutional challenges, edited by Karen Hussey and Stephen R. Dovers, 1-11. Collingwood, Vic: CSIRO Publishing.

Stoker, Gerry. 1998. "Governance as theory: five propositions." International Social Science Journal no. 50 (155):17-28. doi: 10.1111/1468-2451.00106.

Tan, Poh-Ling, Kathleen H. Bowmer, and John Mackenzie. 2012. "Deliberative tools for meeting the challenges of water planning in Australia." Journal of Hydrology no. 474:2-10. doi: 10.1016/j.jhydrol.2012.02.032. 
Thomas, J. S., and Bruce Durham. 2003. "Integrated Water Resource Management: looking at the whole picture." Desalination no. 156:21-28.

Tomlinson, Moya, and Richard Davis. 2010. "Integrating aquatic science and policy for improved water management in Australia." Marine and Freshwater Research no. 61:808-813. doi: 10.1071/mf09224.

Turnhout, E., M. Stuiver, J. Klostermann, B. Harms, and C. Leeuwis. 2013. "New roles of science in society: Different repertoires of knowledge brokering." Science and Public Policy no. 40 (3):354-365. doi: 10.1093/scipol/scs114.

Turton, Anthony R., J. Hattingh, Marius Claassen, Dirk J. Roux, and Peter J. Ashton. 2007. "Towards a Model for Ecosystem Governance: An Integrated Water Resource Management Example." In Governance as a Trialogue: Government-Society-Science in Transition, edited by Anthony R. Turton, Hanlie J. Hattingh, Gillian A. Maree, Dirk J. Roux, Marius Claassen, Wilma F. Strydom, Asit K. Biswas and Cecilia Tortajada, 1-28. Berlin, Heidelberg: Springer.

UNEP. 2007. "GEO4: Water." In Global Environment Outlook 4, 115-156. UNEP.

United Nations. 2002. Report of the World Summit on Sustainable Development. New York: United Nations.

United Nations Conference on Environment Development. 1992. The Rio Declaration on Environment and Development. Rio de Janerio: United Nations.

United Nations Conference on Sustainable Development. 2012 Rio+20 - United Nations Conference on Sustainable Development. Available from http://www.uncsd2012.org/rio20/index.html.

United Nations Department of Economic and Social Affairs. 1992. Earth Summit Agenda 21. Rio de Janerio: United Nations.

van den Hove, Sybille. 2007. "A rationale for science-policy interfaces." Futures no. 39 (7):807826. doi: 10.1016/j.futures.2006.12.004.

Wallington, Tabatha, and Geoffrey Lawrence. 2008. "Making democracy matter: Responsibility and effective environmental governance in regional Australia." Journal of Rural Studies no. 24 (3):277-290. doi: 10.1016/j.jrurstud.2007.11.003.

Wallington, Tabatha, Geoffrey Lawrence, and Barton Loechel. 2008. "Reflections on the Legitimacy of Regional Environmental Governance: Lessons from Australia's Experiment in Natural Resource Management." Journal of Environmental Policy \& Planning no. 10 (1):1-30. doi: 10.1080/15239080701652763.

Wanna, John. 2008. "Collaborative government: meanings, dimensions, drivers and outcomes." In Collaborative governance: a new era of public policy in Australia?, edited by Janine O'Flynn and John Wanna, 3-13. Acton, A.C.T: ANU E Press.

Watson, Robert T. 2005. "Turning science into policy: challenges and experiences from the science-policy interface." Philosophical Transactions of the Royal Society of London. Series B, Biological Sciences no. 360 (1454):471-7. doi: 10.1098/rstb.2004.1601.

Weingart, Peter. 1999. "Scientific expertise and political accountability: paradoxes of science in politics." Science and Public Policy no. 26 (3):151-161. 


\section{ABOUT THE AUTHOR}

Edward Alexander Morgan: Edward Morgan is a $\mathrm{PhD}$ candidate studying the role science can play in sustainability. His research interests lie in the interactions between science and policy, and the use of science in society more widely. His current $\mathrm{PhD}$ research is studying how and why science is used in policy, with a focus on water resource management, in order to better understand the role science can play in contributing to sustainable outcomes. Coming from a background in environmental chemistry, he is interested in how scientific knowledge can cross boundaries within and, more importantly, beyond the scientific community, and how this can help in the search for sustainability. 
The International Journal of Sustainability Policy and Practice is one of four thematically focused journals in the collection of journals that support the Sustainability knowledge community - its journals, book series, conference, and online community.

The journal addresses sustainability agendas and the practices flowing from these in government, corporate, and community sectors.

In addition to traditional scholarly papers, this journal invites presentations of sustainability practicesincluding documentation of case studies and exegeses analyzing the effects of these practices.

The International Journal of Sustainability Policy and Practice is a peer-reviewed scholarly journal.

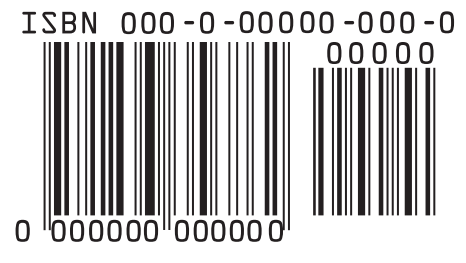

